\title{
Identification and Characterization of Insulin-Like Growth Factor Receptors on Adult Rat Cardiac Myocytes: Linkage to Inositol 1,4,5-Trisphosphate Formation*
}

\author{
ANDREAS H. GUSE $\dagger$, WIELAND KIESS, BARBARA FUNK, ULRIKE KESSLER, \\ INGEBORG BERG, AND GÜNTHER GERCKEN \\ University of Hamburg (A.H.G., I.B., G.G.), Institute of Biochemistry and Food Chemistry, Department of \\ Biochemistry, Martin-Luther-King-Platz 6, D-2000 Hamburg 13, Germany; Children's Hospital (W.K., B.F., \\ U.K.), Department of Paediatric Endocrinology, Cell Biology Laboratory, University of Munich, D-8000 \\ Munich 2, Germany
}

\begin{abstract}
Cultured cardiac myocytes from adult SpragueDawley rats express both insulin-like growth factor-I (IGF-I) receptors and insulin-like growth factor-II/mannose 6-phosphate (IGF-II/Man6P) receptors and respond to IGF-I with a dose-dependent accumulation of inositol 1,4,5-trisphosphate [Ins $\left.(1,4,5) \mathrm{P}_{3}\right]$ and inositol 1,4-bisphosphate $\left[\operatorname{Ins}(1,4) \mathrm{P}_{2}\right]$. Spe cific binding of ${ }^{125}$ I]IGF-I to isolated membranes from cultured cardiac myocytes amounted to $1-1.2 \%$. Binding of $\left[{ }^{125} \mathrm{I}\right] \mathrm{GGF}-\mathrm{I}$ was inhibited by unlabeled IGF-I at nanomolar concentrations and insulin at much higher concentrations. These data suggest that IGF-I binds to its own receptor on rat cardiac myocytes. Competitive binding studies using isolated membranes from cardiac myocytes and ${ }^{225}$ I]IGF-II showed $2-4 \%$ specific binding Binding of $\left[{ }^{125}\right.$ I]IGF-II was inhibited by IGF-II and much less potently by IGF-I and insulin. Immunoglobulin G (IgG) 3637 (an IgG directed against the IGF-II/Man6P receptor) partially inhibited binding of $\left[{ }^{125} \mathrm{I}\right] \mathrm{IGF}$-II whereas nonimmune IgG did not. Affinity cross-linking studies with [ $\left.{ }^{125} \mathrm{I}\right] \mathrm{IGF}$-II and cardiac myocyte membranes and subsequent analysis of the ligand receptor complex using SDS-PAGE and autoradiography showed a radiolabeled band of approximately 250 kilodalton $(\mathrm{kDa})$. The formation of the $\left[{ }^{125}\right.$ I]IGF-II-receptor complex was
\end{abstract}

inhibited by incubation with IGF-II and IgG 3637 but not by insulin or nonimmune IgG.

Western blotting of protein extracts from cultured cardiac myocytes was performed using IgG 3637 and an immunoperoxidase technique for the visualization of the IGF-II/Man6P receptor protein. A specific band at $220 \mathrm{kDa}$ under nonreducing conditions was detected on the blots, providing further evidence for the expression of the IGF-II/Man6P receptor by cardiac myocytes.

The effect of IGFs on the accumulation of inositol phosphates was measured by HPLC analysis of perchloric acid extracts from myo- $\left[{ }^{3} \mathrm{H}\right]$ inositol-labeled cultured cardiac myocytes. IGF-I (60 $\mathrm{ng} / \mathrm{ml})$ stimulated the accumulation both of $\operatorname{Ins}(1,4,5) P_{3}$ and Ins $(1,4) \mathrm{P}_{2}$ after $30 \mathrm{sec}$ by $43 \%$ and $63 \%$. IGF-II (up to $500 \mathrm{ng}$ / $\mathrm{ml}$ ) had no significant effect on inositol phosphate accumulation under the same conditions. However, in the presence of millimolar concentrations of Man6P, IGF-II $(500 \mathrm{ng} / \mathrm{ml})$ also in creased Ins $(1,4,5) \mathrm{P}_{3}$ accumulation by $59 \%$. We conclude that cardiac myocytes from adult rats express IGF receptors and respond to IGFs with the accumulation of $\operatorname{Ins}(1,4,5) \mathrm{P}_{3}$ and Ins $(1,4) \mathbf{P}_{2}$. This effect seems to be mediated by an IGF-I receptor-specific pathway. (Endocrinology 130: 145-151, 1992)
$\mathrm{T}$ HE insulin-like growth factors (IGF-I and IGF-II) are polypeptide hormones closely related to insulin in regard to their amino acid sequence and biological activity $(1,2)$. IGF-I mediates the anabolic action of GH in vivo. The in vivo role of IGF-II is less clear. The IGFs

Received August 2, 1991.

Address all correspondence and requests for reprints to Dr. G. Gercken, University of Hamburg, Institute of Biochemistry and Food Chemistry, Department of Biochemistry, Martin-Luther-King-Platz 6, D-2000 Hamburg 13, Germany.

* This study was supported in part by the Deutsche Forschungsgemeinschaft Grant Ki365-I (to W.K.), by the Nordisk grant for the Study of Growth (Copenhagen, Denmark) (to W.K.), and by the Bundesminister für Forschung und Technologie Grant 0138754A6 (to G.G.).

+ Present address: Max-Planck-Society, Clinical Research Unit for Rheumatology/Immunology at the Institute for Clinical Immunology of the University, Schwabachanlage 10, D-8520 Erlangen, Germany. bind to high affinity receptors present on many cells and in many tissues (3). The IGF-I receptor is a heterotetramer, made of two $\alpha$-binding subunits [(130 kilodaltons $\mathrm{kDa})]$ and two $\beta$-subunits $(95 \mathrm{kDa})$ which contain tyrosine kinase activity. The IGF-I receptor is highly homologous to the insulin receptor and is thought to mediate the biological effect of both IGF-I and IGF-II $(3,4)$. The primary structure of the IGF-II receptor was shown by complementary DNA cloning to be identical to the structure of the cation-independent mannose 6-phosphate receptor (Man6P) (5-9). It is clear that this receptor targets acid hydrolases to lysosomes and also serves as a degradative pathway for IGF-II (10-13). It has also been suggested that the IGF-II/Man6P receptor functions as a signaling receptor for IGF-II mediated biological actions such as stimulation of DNA-synthesis and cell 
proliferation in BALB/c 3T3 cells $(14,15)$, clonal growth of K562 erythroleukemia cells (16), $\mathrm{Na}^{+} / \mathrm{H}^{+}$-exchange in proximal tubular cells from canine kidney (17), stimulation of glycogen synthesis in a human hepatoma cell line (Hep 62) (18). In addition, IGF-II has also been implicated in modulating lysosomal enzyme trafficking via the IGF-II/Man6P receptor $(19,20)$.

IGF receptors have been found in heart tissue $(21,22)$ and a positive inotropic effect of insulin and both IGF-I and IGF-II on isolated fetal rat cardiac myocytes has been described (23).

For many other agonists which elicit positive inotropic responses specific receptors have been found in mammalian heart. In addition, the release of inositol 1,4,5trisphosphate $\left[\operatorname{Ins}(1,4,5) \mathrm{P}_{3}\right]$ as an initial event in receptor-mediated activation of myocardial phosphoinositidase $\mathrm{C}$ has been described for a number of such receptors, for example the $\alpha_{1}$-adrenoceptor (24), the purinoceptor $\mathrm{P}_{2}$ (25), and the histamine $\mathrm{H}_{1}$ receptor (26).

Although the physiological responses to IGFs are well described in several cell types, the signal transduction mechanisms by which IGF-I and IGF-II transmit their cellular signal remain to be elucidated (27).

Contradictory data about the effects of IGFs on inositol trisphosphate generation (28-30) prompted us to investigate 1) the presence and binding characteristics of the IGF-I- and the IGF-II/Man6P-receptor and, 2) the effects of IGF-I and IGF-II on inositol polyphosphate accumulation in cultured cardiac myocytes.

Rat cardiac myocytes were chosen as a model since 1) $\mathrm{InsP}_{3}$ accumulation can be studied directly in a defined primary culture system of a homogenous cell population, and 2) such cells have been reported to respond to IGFs (23).

\section{Materials and Methods}

Cell culture, myo- $\left[{ }^{3} H\right]$ inositol labeling and stimulation experiments

The procedure of isolating cardiac myocytes from adult Sprague-Dawley rats (10-14 weeks old, obtained from the Zentralinstitut für Versuchstierzucht, Hannover, Germany) was carried out as described recently (31). The use of the animals was approved by the Freie und Hansestadt Hamburg, Gesundheitsbehörde. In brief, hearts were removed and perfused in a recirculating manner for $30 \mathrm{~min}$ with $60 \mathrm{ml}$ Krebs-Ringerbicarbonate buffer containing $5500 \mathrm{U}$ collagenase (type II, Biochrorn, Berlin, Germany). Then atria were removed and the ventricles were cut in $20 \mathrm{ml} \mathrm{Krebs}$-Ringer-bicarbonate buffer containing $2750 \mathrm{U}$ collagenase. Rod-shaped cardiomyocytes were obtained by two centrifugation steps $(20 \times \mathrm{g}, 60 \mathrm{sec})$. The $\mathrm{Ca}^{++}$-concentration was raised in 10 steps up to $0.5 \mathrm{mM}$, followed by another centrifugation step $(20 \times g, 60 \mathrm{sec})$. The myocytes were then incubated for $2 \mathrm{~h}$ in medium 199 (Biochrom) containing fetal calf serum ( $4 \%$ ), gentamycin, and $1.8 \mathrm{mM}$ $\mathrm{Ca}^{++}$. Nonadherent cells were removed and the rod-shaped myocytes were labeled for $6 \mathrm{~h}$ in serum-free medium $199 \mathrm{con}$ - taining myo- $\left[{ }^{3} \mathrm{H}\right]$ inositol $(20 \mu \mathrm{Ci} / \mathrm{ml}, \mathrm{SA}, 80-120 \mathrm{Ci} / \mathrm{mmol})$. After labeling, the myocytes were incubated in Krebs-RingerHEPES buffer containing $10 \mathrm{mM} \mathrm{LiCl}$ (and $10 \mu \mathrm{M}$ propranolol when (-)-noradrenaline was used for stimulation) and then exposed to IGFs, (-)-noradrenaline, or carbamoylcholine for $30 \mathrm{sec}$. The incubation was terminated by addition of $\mathrm{HClO}_{4}$ $(10 \%, \mathrm{vol} / \mathrm{vol})$. Samples were transferred to Eppendorf tubes, precipitated protein was removed by centrifugation $(10,000 \times$ $\mathrm{g}, 10 \mathrm{~min}$ ), and the supernatants were titrated to $\mathrm{pH} 4$ to 5 . $\mathrm{KClO}_{4}$ was removed by centrifugation $(10,000 \times g, 10 \mathrm{~min})$ and the supernatants were subjected to HPLC analysis.

\section{HPLC analysis of inositol phosphates}

Inositol phosphates were separated by anion exchangeHPLC using a Merck-Hitachi LC-5000 liquid controller and a L-6000 pump equipped with a Partisil 10 SAX column (Whatman, Clifton, NJ) by a method originally introduced by Dean and Moyer (32). The method was modified to elute $\mathrm{InsP}_{4}$ from the column as described recently (24). Quantitation of inositol phosphate accumulation was carried out by liquid scintillation counting (Packard TriCarb 460, Frankfurt, Germany) of $1 \mathrm{ml}$ or $0.5 \mathrm{ml}$ fractions mixed with $5 \mathrm{ml}$ or $2.5 \mathrm{ml}$ Ready Value scintillation cocktail (Beckman, München, Germany) for 9 min or $30 \mathrm{~min}$. These long counting times were necessary to obtain reliable data from samples with low radioactivity.

\section{Preparation of cardiomyocyte membranes}

Cardiac myocytes from one rat heart were homogenized in 2 $\mathrm{ml}$ membrane isolation buffer (10 mM HEPES, $230 \mathrm{mM}$ mannitol, $70 \mathrm{mM}$ sucrose, $50 \mathrm{ng} / \mathrm{ml}$ phenylmethylsulfonylfluoride, $50 \mathrm{ng} / \mathrm{ml}$ antipain, $\mathrm{pH} 7.0$ ) by 10 strokes of a glass/teflonhomogenizer. Crude membranes were prepared by two centrifugation steps: removal of cell fragments and nuclei at $1000 \times \mathrm{g}$ (10 min, $4 \mathrm{C}$ ) and separation of the cytosolic fraction from the total membrane fraction at $100,000 \times \mathrm{g}(60 \mathrm{~min}, 4 \mathrm{C}$, Kontron centrifuge T-2060).

\section{Solubilization of IGF-II/Man6P-receptors}

Cultured myocytes were treated with Tris buffer containing $20 \mathrm{~mm}$ Tris-HCl, pH 7.4, $2 \%$ (vol/vol) Triton X-100, $50 \mathrm{ng} / \mathrm{ml}$ phenylmethylsulfonylfluoride, $50 \mathrm{ng} / \mathrm{ml}$ antipain (about $1 \mathrm{ml}$ / $2.4 \times 10^{5}$ cells) for $30 \mathrm{~min}$ at $4 \mathrm{C}$. The lysate was harvested with a rubber policeman and transferred to Eppendorf tubes and stored frozen at $-20 \mathrm{C}$.

\section{Polyacrylamide gel electrophoresis (PAGE)}

Sodium dodecyl sulfate (SDS)-PAGE was performed using the discontinuous buffer system of Laemmli (6\% acrylamidebis) (33).

\section{Antireceptor antibody}

Antiserum 3637 has been raised against IGF-II receptor that had been purified from Swarm rat chondrosarcoma cells by affinity chromatography on IGF-II sepharose (13). The antibody is specific for rat IGF-II/Man6P receptor and does neither recognize the IGF-I or insulin receptor nor the IGF binding proteins $(13,34)$. Also, antibody 3637 does not recognize the cation-dependent $46 \mathrm{kDa}$ Man6P receptor (35). 


\section{Western blotting of IGF-II/Man6P receptors}

The Western blotting procedure was essentially performed as described previously (13). In brief, cardiac myocytes were solubilized and subjected to SDS-PAGE $(6 \%$ gel) under nonreducing conditions. The proteins were transferred onto nitrocellulose paper by electroelution and the nitrocellulose sheets incubated with antiserum 3637. Antirabbit-immunoglobulin G (IgG) antiserum and a biotin-avidin horse radish peroxidase system (Vectastain) were used to detect receptor-antibody complexes on the nitrocellulose sheets.

\section{Binding of [ $\left.{ }^{25} I\right] I G F-I$ and [25I]IGF-II to cardiomyocyte} membranes

Binding of $\left[{ }^{125} \mathrm{I}\right] \mathrm{IGF}-\mathrm{I}$ and $\left[{ }^{125} \mathrm{I}\right] \mathrm{IGF}$-II to cardiomyocyte membranes $(0.85 \mathrm{mg}$ membrane protein $/ 400 \mu \mathrm{l})$ was carried out in $1.5 \mathrm{ml}$ microfuge tubes for $2 \mathrm{~h}$ at room temperature in Dulbecco's modified Eagle's medium (DMEM) with $0.2 \%$ BSA with labeled and unlabeled peptides or IgGs present as indicated. Bound from free radioactivity was separated by centrifugation in a Hettich microfuge.

\section{Affinity cross-linking of $I^{25} I J I G F-I I$ to cardiomyocyte membranes}

Affinity cross-linking was carried out using disuccinimidyl suberate (DSS) as the cross-linking reagent (Pierce Chemicals, Rockford, IL). Crude membranes from rat cardiac myocytes were incubated with radioligands, unlabeled polypeptides, and $\mathrm{IgGs}$ as indicated for $2 \mathrm{~h}$ at room temperature in DMEM with $1 \%$ BSA. The membranes were centrifuged, washed once with cold PBS, $\mathrm{pH} 7.4$, and resuspended in DMEM with $0.1 \mathrm{mM}$ DSS without BSA. After $10 \mathrm{~min}$ at room temperature, the reaction was quenched with $10 \mathrm{~mm}$ Tris, $1 \mathrm{~mm}$ EDTA solution for $5 \mathrm{~min}$ at room temperature, the samples were centrifuged in a microfuge for $3 \mathrm{~min}$, and the liquid was discarded. Sample buffer was added, and the samples were boiled for $3 \mathrm{~min}$ and analyzed by SDS-PAGE ( $0.1 \%$ SDS, $6 \%$ acrylamide) and subsequent autoradiography (Kodak X-Omat film).

\section{Materials}

Recombinant human IGF-I and IGF-II were a kind gift from Dr. K. Müller, Ciba Geigy (Basel, Switzerland) or donated by Eli Lilly (Indianapolis, IN). Rat IGF-II (MSA-III-2) was kindly given by Dr. S. P. Nissley, National Institutes of Health (Bethesda, MD). Insulin and mannose 6-phosphate were purchased from Sigma Biochemicals (Taufkirchen, Germany). IGF-II was radioiodinated by a modified chloramine-T procedure to specific activities of $50-100 \mathrm{Ci} / \mathrm{g}(36)$. [ ${ }^{125}$ I]IGF-I (SA, $2000 \mathrm{Ci}$ / mmol) was purchased from Amersham Buchler (Braunschweig, Germany).

All other materials were obtained as described in an earlier paper (31).

\section{Results}

Rat cardiac myocytes express high affinity binding sites for $L^{125} I J I G F-I$ and $I^{125} I J I G F-I I$

Competitive binding studies using crude membranes from isolated rat cardiac myocytes and [ ${ }^{125}$ I]IGF-I showed $1-1.2 \%$ specific binding. Half-maximal displace- ment of $\left.{ }^{125} \mathrm{I}\right] \mathrm{IGF}-\mathrm{I}$ binding occurred at approximately $1.5 \mathrm{ng} / \mathrm{ml}$ at a membrane protein concentration of 2.125 $\mathrm{mg} / \mathrm{ml}$. Insulin at high concentrations $(5-25 \mu \mathrm{g} / \mathrm{ml})$ also completely blocked binding of ${ }^{125}$ I]IGF-I to rat cardiac myocyte membranes. This result strongly suggests binding of $\left[{ }^{125} \mathrm{I}\right] \mathrm{IGF}-\mathrm{I}$ to the IGF-I receptor present on cardiac myocytes of adult rat hearts (Fig. 1A).

Competitive binding studies using crude membranes from isolated cardiac myocytes and $\left[{ }^{125}\right.$ I]IGF-II showed $2-4 \%$ specific binding. Half-maximal displacement of $\left[{ }^{125} \mathrm{I}\right] \mathrm{IGF}$-II binding occurred at $30 \mathrm{ng} / \mathrm{ml}$ IGF-II at a membrane protein concentration of $2.125 \mathrm{mg} / \mathrm{ml}$ (Fig. 1B). IGF-I was much less potent, anti IGF-II/Man6P receptor IgG competed partially, whereas nonimmune rabbit IgG was less effective (data not shown). Interestingly, insulin at high concentrations $(5-25 \mu \mathrm{g} / \mathrm{ml})$ also displaced $\left[{ }^{125} \mathrm{I}\right] \mathrm{IGF}$-II binding partially (data not shown). These results suggest that $\left[{ }^{125}\right.$ I]IGF-II under the conditions of these experiments might bind both to the IGFII/Man6P receptor (IgG 3637 competable site) and the IGF-I receptor (insulin competable site).

Affinity cross-linking experiments were performed using cardiomyocyte membranes, $\left[{ }^{125}\right.$ I]IGF-II and DSS suberate as the cross-linking agent. Analysis of ligandreceptor complexes by SDS-PAGE and autoradiography was carried out as described in Materials and Methods.
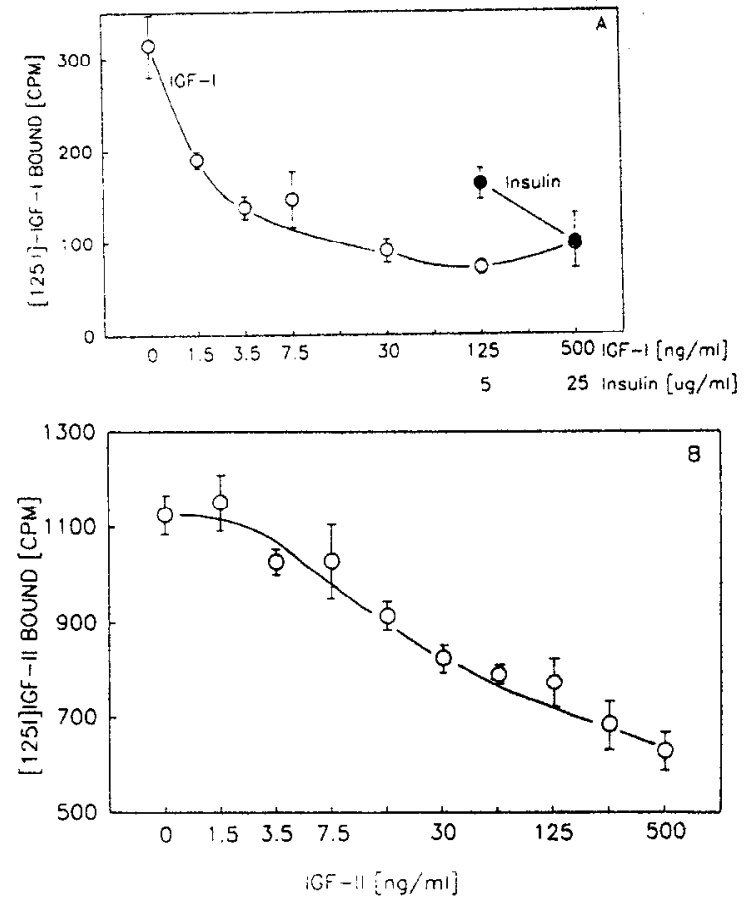

FIG. 1. Binding of $\left[{ }^{125} I\right] I G F-I$ and $\left[{ }^{125} I\right]$ IGF-II to crude membranes from isolated cardiac myocytes. A, $\left[{ }^{125} I\right] I G F-I$ was incubated with cardiac myocyte membranes $(0.85 \mathrm{mg}$ membrane protein $/ 400 \mu \mathrm{l})$ in the presence of various concentrations of unlabeled IGF-I or insulin for 2.5 $\mathrm{h}$ as described in Materials and Methods. B, $\left[{ }^{125} \mathrm{I}\right] \mathrm{IGF}$-II was incubated with cardiac myocyte membranes $(0.85 \mathrm{mg}$ membrane protein $/ 400 \mu \mathrm{l})$ in the presence of various concentrations of unlabeled IGF-II for $2.5 \mathrm{~h}$ as described in Materials and Methods. Data are mean values \pm SD from three independent experiments. 
A specific band with an approximate mol wt of $250 \mathrm{k}$ under reducing conditions was detected. IGF-II $(2 \mu \mathrm{g} /$ $\mathrm{ml})$ and IgG $3637(180 \mu \mathrm{g} / \mathrm{ml})$ completely abolished the formation of this band whereas nonimmune IgG and insulin did not (Fig. 2A). We conclude from these data that cardiac myocytes express IGF-II/Man6P receptors. Further evidence for the presence of IGF-II/Man6P receptors on cardiac myocytes is derived from Western blotting of the IGF-II/Man6P receptor in protein extracts from cultured cardiac myocytes. A specific band
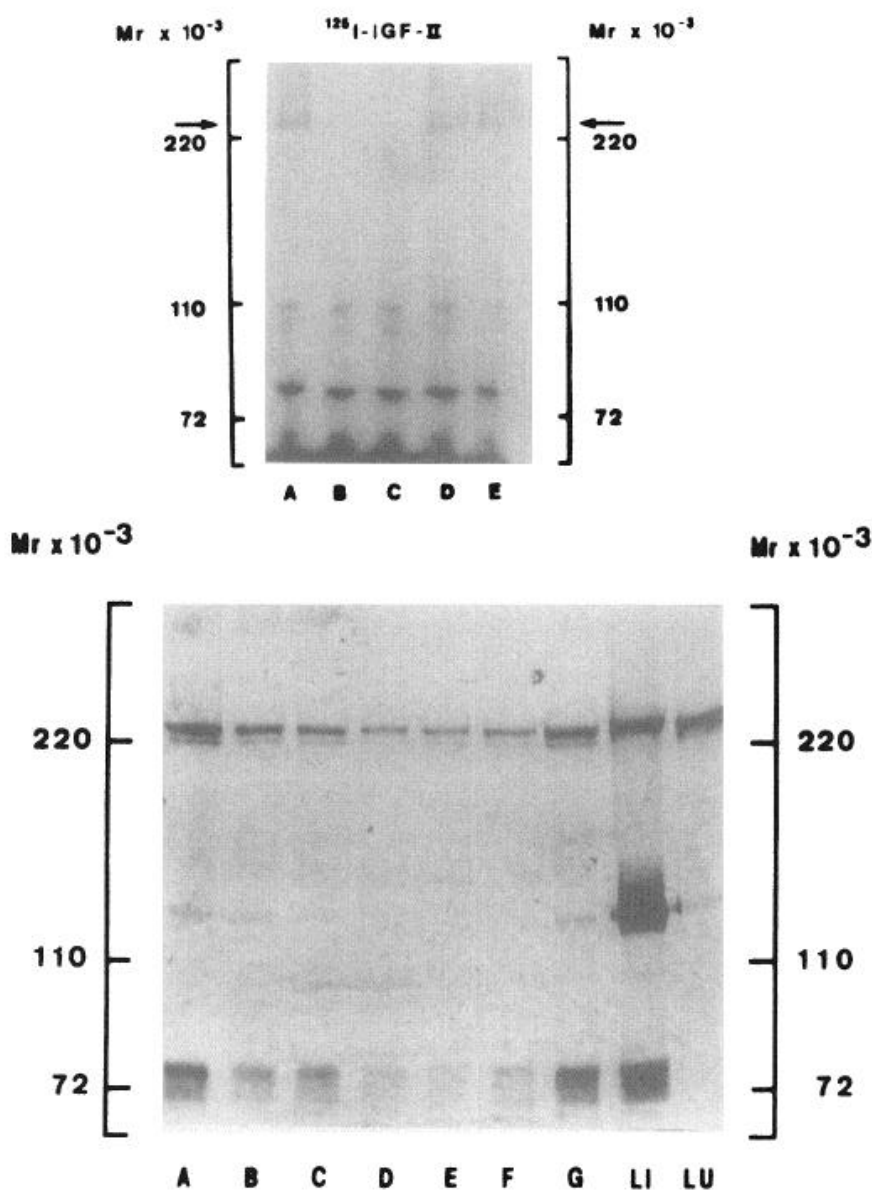

FIG. 2. Top, Affinity cross-linking of [ ${ }^{125}$ I]IGF-II to rat cardiomyocyte membranes. [ ${ }^{125}$ I]IGF-II was incubated with crude membranes from isolated cardiac myocytes, and DSS was used as the cross-linking reagent as described in Materials and Methods in the absence (lane A) or presence (lane B) of $2 \mu \mathrm{g} / \mathrm{ml} \mathrm{IGF-II,} \mathrm{and} \mathrm{in} \mathrm{the} \mathrm{presence} \mathrm{of} 180 \mu \mathrm{g} /$ $\mathrm{ml} \mathrm{IgG} 3637$ (lane C), $180 \mu \mathrm{g} / \mathrm{ml}$ nonimmune IgG (lane D), or $25 \mu \mathrm{g} /$ $\mathrm{ml}$ insulin (lane E). Bottom, Western blotting of the solubilized IGFII/Man6P receptor from cultured rat cardiac myocytes. Western blotting of IGF-II/Man6P receptors was performed as described in Materials and Methods. In brief, solubilized extracts from cultured cardiac myocytes (lanes $A-G$ ) and extracts from rat liver (lane LI) and rat lung (lane LU) were subjected to SDS-PAGE under nonreducing conditions. Proteins were then transferred onto nitrocellulose paper and incubated with antiserum 3637. Antirabbit-IgG antiserum and a biotinavidin horse raddish peroxidase system were used to detect receptorantibody complexes. Protein bands of lower molecular weights were also seen when nonimmune rabbit serum was used instead of antiserum 3637 and therefore represent nonspecifically stained proteins. One representative blot out of three independent experiments is shown. with an apparent mol mass of $220 \mathrm{k}$ under nonreducing conditions was detected in all protein extracts [seven different protein preparations from three independent cardiac myocyte preparations (Fig. 2B)]. The protein bands at about 72 to $80 \mathrm{kDa}$ were also seen when nonimmune rabbit serum was used instead of antiserum 3637 , indicating a nonspecific interaction with the detection system rather than receptor degradation products.

\section{IGFs stimulate inositol polyphosphate accumulation in cardiac myocytes}

Inositol phosphates were measured after stimulation of cardiac myocytes with IGFs, (-)-noradrenaline, carbamoylcholine, or IGF-II in combination with Man6P as described in Materials and Methods. Stimulation of cultured cardiac myocytes with nanomolar concentrations of IGF-I for $30 \mathrm{sec}$ resulted in a significant increase both in $\operatorname{Ins}(1,4,5) \mathrm{P}_{3}$ and inositol 1,4-bisphosphate $\left[\operatorname{Ins}(1,4) \mathrm{P}_{2}\right]$ indicating rapid activation of phosphoinositidase $\mathrm{C}$ as well as rapid degradation of $\operatorname{Ins}(1,4,5) \mathrm{P}_{3}$ by 5 -phosphomonoesterase activity (Fig. 3). Other inositol phosphate compounds, in particular intermediates of the inositol tetrakisphosphate pathway such as $\operatorname{Ins}(1,3,4,5) \mathrm{P}_{4}$, $\operatorname{Ins}(1,3,4) \mathrm{P}_{3}, \operatorname{Ins}(1,3) \mathrm{P}_{2}$, and $\operatorname{Ins}(3,4) \mathrm{P}_{2}$ were not affected by IGF-I during the early stimulation period (data not shown).

IGF-II was used for stimulation alone or in combination with Man6P as it was recently reported (29) that Man6P enhances the IGF-II-mediated activation of phosphoinositidase C. Even high concentrations of IGFII $(500 \mathrm{ng} / \mathrm{ml})$ had no significant stimulatory effect on inositol phosphate accumulation after $30 \mathrm{sec}$ (Fig. 3). Interestingly, when IGF-II $(250 \mathrm{ng} / \mathrm{ml}$ or $500 \mathrm{ng} / \mathrm{ml})$ was added in the presence of Man6P (5 mM), a significant increase of $\operatorname{Ins}(1,4,5) \mathrm{P}_{3}$ was observed (Fig. 3). Neither the direct phosphorylation or dephosphorylation products of $\operatorname{Ins}(1,4,5) \mathrm{P}_{3}, \operatorname{Ins} \mathrm{P}_{4}$, and $\operatorname{Ins}(1,4) \mathrm{P}_{2}$ (Fig. 3), nor any other known inositol phosphates (data not shown) were found to be elevated within $30 \mathrm{sec}$ of IGF-II or combined IGF-II/Man6P-treatment of cardiac myocytes. Man6P at millimolar concentrations had no effect on Ins $(1,4,5) \mathrm{P}_{3}$ accumulation when tested alone.

Stimulation of inositol phosphate accumulation by pharmacological agents via $\alpha_{1}$-adrenergic and muscarinic cholinergic receptors, which are coupled to cardiac phosphoinositidase $\mathrm{C}$, induced a more pronounced effect on inositol polyphosphate accumulation than IGF-I or IGFII/Man6P (Table 1). In particular $\alpha_{1}$-adrenergic stimulation by $50 \mu \mathrm{M}(-)$-noradrenaline (in the presence of 10 $\mu \mathrm{M}$ propranolol) provoked an approximately 10-fold higher Ins $(1,4,5) \mathrm{P}_{3}$ release when compared with the stimulatory effect of nanomolar concentrations of IGF-I.

\section{Discussion}

It has been suggested in the literature that IGF receptors are present in rat heart $(21,22)$. We demonstrate 


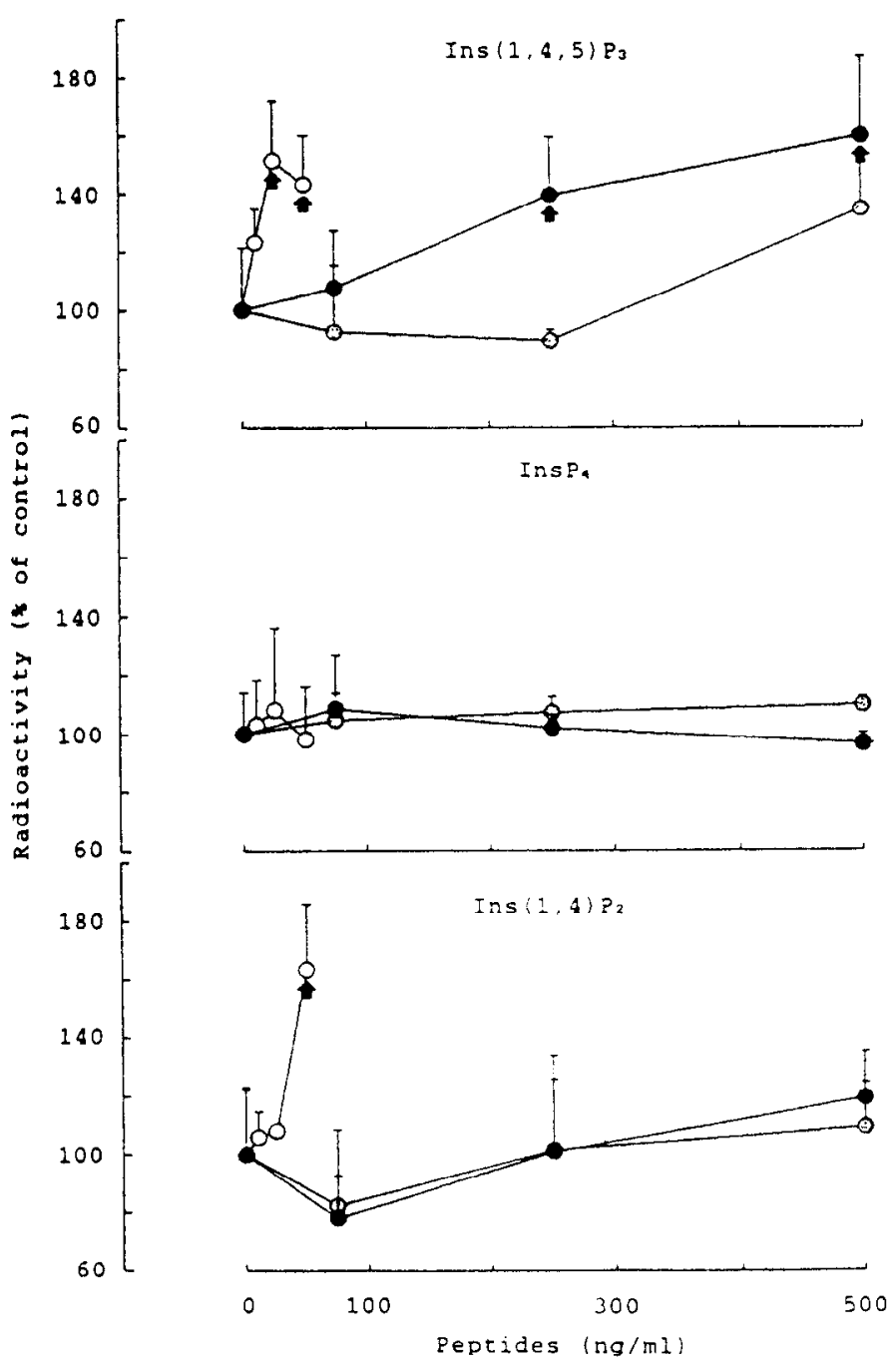

FIG. 3. Effect of IGFs on inositol polyphosphate accumulation in rat cardiac myocytes. Cardiac myocytes were cultured and prelabeled with myo- $\left[{ }^{3} \mathrm{H}\right]$ inositol as described in Materials and Methods. Stimulation of cells with IGF-I (O), IGF-II (O), or IGF-II in combination with Man6P (5 mM; O) was carried out in KRH-buffer at $38 \mathrm{C}$ for $30 \mathrm{sec}$. Neutralized perchloric acid extracts were analyzed for inositol phosphates by HPLC. Values are presented as mean \pm SD. $(n=3-5)$. Radioactivity of inositol phosphates in samples from unstimulated cells was (in desentegrations per $\min / 10^{6}$ cells): $\operatorname{Ins}(1,4,5) \mathrm{P}_{3} 180, \operatorname{Ins} \mathrm{P}_{4} 24$, Ins $(1,4) P_{2} 420$. Usually, $3-3.5 \times 10^{5}$ cells were plated on one culture dish and extracts from three to four dishes were pooled for analysis. The liquid counting efficiency ranged between $30 \%$ and $40 \%$ depending on the salt content of the samples. For an accurate quantification of radioactivity long counting periods were chosen, e.g. $3 \times 3 \mathrm{~min}$ or $3 \times$ $10 \mathrm{~min} / \mathrm{sample}$. Arrows indicate significant differences from control values according to analysis of variance (multifactor analysis of variance, $P \leq 0.05$ ).

here that both IGF-I receptors and IGF-II/Man6P receptors in rat heart are actually expressed by cardiac myocytes.

Sklar et al. (21) using total protein lysates from rat hearts and immunoblotting demonstrated the expression of IGF-II/Man6P receptors in rat hearts at different ages. Engelmann et al. (22) used total membrane preparations from adult rat hearts and binding and affinity
TABLE 1. Effect of various agonists on inositol phosphate accumulation in rat cardiac myocytes

\begin{tabular}{|c|c|c|c|}
\hline \multirow[b]{2}{*}{ Control } & \multirow{2}{*}{$\begin{array}{r}\operatorname{Ins}(1,4,5) \mathrm{P}_{3} \\
\text { (fold st }\end{array}$} & \multirow{2}{*}{$\frac{\operatorname{InsP}_{4}}{1.00 \pm 0.50}$} & \multirow{2}{*}{$\frac{\begin{array}{c}\operatorname{Ins}(1,4) \mathrm{P}_{2} \\
\text { control })\end{array}}{1.00 \pm 0.17}$} \\
\hline & & & \\
\hline $\mathrm{IGF}-\mathrm{I}(50 \mathrm{ng} / \mathrm{ml})$ & $1.48 \pm 0.21^{a}$ & $1.08 \pm 0.28$ & $1.64 \pm 0.36^{a}$ \\
\hline IGF-II $(500 \mathrm{ng} / \mathrm{ml})$ & $1.34 \pm 0.20$ & $1.10 \pm 0.03$ & $1.09 \pm 0.26$ \\
\hline $\begin{array}{l}\mathrm{IGF}-\mathrm{II} / \mathrm{Man} 6 \mathrm{P}(500 \mathrm{ng} / \\
\mathrm{ml}, 5 \mathrm{mM})\end{array}$ & $1.59 \pm 0.27^{a}$ & $0.97 \pm 0.04$ & $1.19 \pm 0.52$ \\
\hline $\begin{array}{l}\text { Noradrenaline }(50 \mu \mathrm{M}) \\
\quad(+ \text { propranolol } 10 \mu \mathrm{M})\end{array}$ & $6.19 \pm 1.19^{h}$ & $10.06 \pm 0.97^{h}$ & $7.10 \pm 1.32^{b}$ \\
\hline Carbachol $(100 \mu \mathrm{M})$ & $1.99 \pm 0.42^{b}$ & $4.92 \pm 1.74^{b}$ & $1.78 \pm 0.25^{b}$ \\
\hline
\end{tabular}

Cardiac myocytes were cultured and prelabeled with myo- $\left[{ }^{3} \mathrm{H}\right]$ inositol as described in Materials and Methods. Stimulation was carried out in KRH-buffer at $38 \mathrm{C}$ for 30 sec. Neutralized perchloric acid extracts were analyzed for inositol phosphates by HPLC. Values are presented as mean \pm SD $(n=4-9)$. Radioactivity of inositol phosphates in samples from unstimulated cells was (in disintegration per $\mathrm{min} / 10^{6}$ cells): Ins $(1,4,5) \mathrm{P}_{3} 180, \operatorname{Ins} \mathrm{P}_{4} 24, \operatorname{Ins}(1,4) \mathrm{P}_{2} 420$.

a Significant differences to control values according to analysis of variance (multifactor analysis of variance, $P \leq 0.05$ ).

${ }^{b} P \leq 0.01$.

cross-linking studies to conclude that IGF-I receptors are present in rat heart. The cultured cardiac myocytes used in our experiments are homogenous preparations with $5 \pm 1.8 \%(n=6)$ of contaminating cells (Gercken, G., and Achterberg, V., unpublished results). Taking into account that the myocyte content of the whole heart is only some $12 \%$ of the total number of cells (37), the use of an about $95 \%$ pure population means a great improvement compared to conventional models, e.g. whole heart preparations or papillary muscles. Using membranes from such cardiac myocytes, we found that both $\left[{ }^{125} \mathrm{I}\right]$ IGF-I and [ ${ }^{125}$ I]IGF-II bind to specific high affinity binding sites with the binding characteristics of the IGF-I and the IGF-II/Man6P receptor respectively. Our affinity cross-linking and immunoblotting data further confirm the presence of the IGF-II/Man6P receptor on adult rat cardiac myocytes. Most importantly our findings indicate not only the presence of the IGF receptors on cardiac myocytes, but also that the IGF-I receptor might actually be coupled to phosphoinositidase $\mathrm{C}$ in these highly differentiated cells. Stimulation of cardiac myocytes with nanomolar concentrations of IGF-I led to a significant increase of $\operatorname{Ins}(1,4,5) \mathrm{P}_{3}$ and $\operatorname{Ins}(1,4) \mathrm{P}_{2}$. Other inositol phosphorylation or dephosphorylation products were not affected by stimulation of cells with IGF-I. The finding that the IGF-I receptor is linked to phosphoinositidase $\mathrm{C}$ is consistent with a very recent report from Takasu et al. (38). These authors found a dose-dependent effect of IGF-I $\left(\mathrm{EC}_{50} \approx 10 \mathrm{ng} / \mathrm{ml}\right)$ on inositol trisphosphate formation and $\mathrm{Ca}^{++}$-release in cultured porcine thyroid cells. In contrast to the finding of Takasu et al. in thyroid cells (38), we could not detect a marked increase in inositol monophosphate (InsP ${ }_{1}$ ) after treatment with IGF-I in cardiac myocytes. This discrepancy may be due to the different incubation periods used. 
Increased accumulation of $\operatorname{Ins} \mathrm{P}_{1}$ in cardiac myocytes was observed only after $15 \mathrm{~min}$ of muscarinic cholinergic stimulation (31). Therefore it seems unlikely that IGFI, which exerts a weaker effect than carbamoylcholine in cardiac myocytes, leads to a significant increase of Ins $\mathrm{P}_{1}$ after 30 sec. Alternatively, IGF-I might elucidate distinct effects on the accumulation of inositol phosphates in different cell systems.

It has been reported in the literature that IGF-I induces a positive inotropic effect in cardiac myocytes (23). The concentration of IGF-I needed for maximal inotropic effects in the study by Vetter et al. (23) are in the same range as the concentrations of IGF-I needed to induce inositol phosphate accumulation in our study. Stimulation of other myocardial receptors such as the $\alpha_{1}$-adrenoceptor $(24,39)$, the histamine receptor $\mathrm{H}_{1}(26)$, and the purinoceptor $P_{2}(25)$ resulted in phosphoinositidase $\mathrm{C}$ activation as well as in an increase in force of contraction. Thus, it might well be that IGF-I exerts a positive inotropic effect in cardiac myocytes via a phosphoinositidase $\mathrm{C}$-mediated second messenger pathway. Although the increase of Ins $(1,4,5) \mathrm{P}_{3}$ was markedly lower after IGF- than after $\alpha_{1}$-adrenergic- or muscarinic cholinergic stimulation in cardiac myocytes, it should be mentioned, that for these studies $(24,31)$ pharmacological agents at very high concentrations have been used. Therefore it appears unlikely that physiological concentrations of IGFs would exert the same increases in inositol phosphates. This suggestion is further supported by the finding that stimulation of $\alpha_{1}$-adrenoceptors without $\beta$-adrenoceptor blockade (an experimental design that mimics a more physiological situation) resulted in a markedly diminished increase in all inositol phosphates in cardiac myocytes (Guse, A. H., I. Berg, and G. Gercken, in press).

IGF-II, in the presence of millimolar concentrations of Man6P seems to mediate its, albeit weak, effect on inositol phosphate formation via the IGF-I receptor as is suggested by the high concentration needed. Many other biological effects of IGF-II are also thought to be mediated via the IGF-I receptor $(13,40)$. In renal proximal tubular membranes, to our knowledge the only system where IGF-II-induced Ins $(1,4,5) \mathrm{P}_{3}$ formation was observed, a 3 - to 4 -fold increase of $\operatorname{Ins}(1,4,5) \mathrm{P}_{3}$ was measured after stimulation with $10^{-9} \mathrm{M}$ IGF-II $(\sim 7 \mathrm{ng} /$ $\mathrm{ml})$, whereas IGF-I even at micromolar concentrations had no effect (28). In cardiac myocytes, we were unable to provoke any effect on inositol phosphate accumulation at such low concentrations of IGF-II (data not shown). Interestingly, in a second report Rogers and Hammerman (29) showed that millimolar concentrations of Man6P enhanced IGF-II-induced Ins $(1,4,5) \mathrm{P}_{3}$-formation in proximal tubular membranes. Man6P also increased the binding of IGF-II to the IGF-II/Man6P receptor in several cell systems $(19,29,41,42)$. However, the stimulatory effect of Man6P is not a universal finding and seems to depend upon the ligand and the system studied $(7,43,44)$. It is possible that millimolar concentrations of Man6P may have modulated the amount of IGF-II available for binding to the effective receptor system resulting in the leftwardshift of the dose-response curve for IGF-II in our as well as in Rogers and Hammerman's study (29).

Finally, in another recent study Thrakker et al. (30) reported that in isolated human hepatocytes IGF-I, IGFII, and insulin had no stimulatory effect on inositol phosphate accumulation. This lack of effect of IGFs may potentially be explained by the method used for measuring the inositol phosphate response. Thrakker et al. (30) counted an aliquot from the trichloroacetic supernatant of hepatocyte lysates without any separation of inositol from the inositol phosphates. Thus, most of the radioactivity measured in their study might have been $\left[{ }^{3} \mathrm{H}\right]$ inositol and only a minor part represented $\left[{ }^{3} \mathrm{H}\right]$ inositol phosphates. Small changes in inositol phosphate accumulation, especially those of $\operatorname{Ins}(1,4,5) \mathrm{P}_{3}$ could not have been detected in such a system.

In conclusion, our results indicate not only the presence of IGF receptors on cardiac myocytes, but also evidence the linkage of the IGF-I receptor to the inositol phosphate system.

\section{Acknowledgments}

We would like to thank Dr. S. P. Nissley for critically reading the manuscript. IGFs were generous gifts of Dr. K. Müller, Dr. S. P. Nissley and Dr. K. von Figura (Göttingen, Germany). We are also grateful to H. Schröder-Borm and D. Jebens for expert technical assistance.

\section{References}

1. van Wyk JJ 1984 The somatomedins: biological actions and physiological control mechanisms. In: $\mathrm{Li} \mathrm{CH}$ (ed) Hormonal Proteins and Peptides. Academic Press, Orlando, FL, pp 82-125

2. Humbel RE 1984 Insulin-like growth factors/somatomedins, and multiplication activating activity: chemistry. In: $\mathrm{Li} \mathrm{CH}$ (ed) Hormonal Proteins and Peptides. Academic Press, Orlando, FL, pp 57-59

3. Rechler MM, Nissley SP 1985 The nature and regulation of the receptors for insulin-like growth factors. Annu Rev Physiol 47: 425-442

4. Ulrich A, Gray A, Tam AW, Yang-Feng T, Tsubokawa M, Collins C, Henzel W, LeBon T, Kathuria S, Chen E, Jacobs S, Francke U, Ramachandran J, Fujita-Yamaguchi Y 1986 Isolation of the human IGF-I receptor gene using a single synthetic DNA probe. EMBO J 5:2503-2512

5. MacDonald RG, Pfeffer SR, Coussins L, Tepper MA, Brocklebank CM, Mole JE, Anderson JK, Chen E, Czech MP, Ullrich A 1988 A single receptor binds both insulin-like growth factor II and mannose 6-phosphate. Science 239:1134-1137

6. Morgan DO, Edman JC, Standring DN, Fried VA, Smith MC, Roth RA, Rutter WJ 1987 Insulin-like growth factor II receptor as a multifunctional binding protein. Nature 329:301-307

7. Tong PY, Tollefsen SE, Kornfeld S 1988 The cation-independent mannose 6-phosphate receptor binds insulin-like growth factor II. J Biol Chem 263:2585-2588

8. Oshima A, Nolan CM, Kyle JW, Grubb JH, Sly WS 1988 The human cation-independent mannose 6-phosphate receptor. Cloning and sequence of the full length cDNA and expression of functional receptor in COS cells. I Biol Chem 263:2553-2562 
9. Lobel P, Dahms NM, Breitmeyer J, Chirgwin JM, Kornfeld S 1987 Cloning of the bovine $215-\mathrm{kDa}$ cation-independent mannose 6 phosphate receptor. Proc Natl Acad Sci USA 84:2233-2237

10. Kornfeld S 1987 Trafficking of lysosomal enzymes. FASEB J $1: 462-468$

11. von Figura K, Hasilik A 1986 Lysosomal enzymes and their receptors. Annu Rev Biochem 55:167-193

12. Dahms NM, Lobel P, Kornfeld S 1989 Mannose 6-phosphate receptors and lysosomal targeting. J Biol Chem 264:12115-12118

13. Kiess W, Haskell JF, Lee L, Greenstein LA, Miller BE, Aarons AL, Rechler MM, Nissley SP 1987 An antibody that blocks insulin. like growth factor (IGF) binding to the type II IGF receptor is neither an agonist nor an inhibitor of IGF-stimulated biologic responses in L6 myoblusts. J Biol Chem 262:12745-12751

14. Nishimoto I, Hata Y, Ogata E, Kojima I 1987 Insulin-like growth factor II stimulates calcium influx in competent BALB/c $3 \mathrm{~T} 3$ cells primed with epidermal growth factor. J Biol Chem 262:1212012126

15. Nishimoto I, Ohkuni Y, Ogata E, Kojima I 1987 Insulin-like growth factor II increases cytoplasmic free calcium in competent BALB/c 3'T3 cells treated with epidermal growth factor. Biochem Biophys Res Commun 142:275-286

16. Tally M, Li CH, Hall K 1987 IGF-2 stimulated growth mediated by the somatomedin type 2 receptor. Biochem Biophys Res Commun 148:811-816

17. Mellas J, Gavin JR III, Hammerman MR 1986 Multiplicationstimulating activity-induced alkalinization of canine renal proximal tubular cells. J Biol Chem 261:14437-14442

18. Hari J, Pierce SB, Morgan DO, Sara V, Smith MC, Roth RA 1987 The receptor for insulin-like growth factor II mediates an insulinlike response. EMBO J 6:3367-3371

19. Braulke T, Tippmer $S$, Neher E, von Figura K 1989 Regulation of the mannose 6-phosphate/IGF-II receptor expression at the cell surface by mannose 6-phosphate, insulin-like growth factors and epidermal growth factor. EMBO J 8:681-686

20. Kiess W, Thomas CL, Greenstein LA, Lee L, Sklar MM, Rechler MM, Sahagian GG, Nissley SP 1989 Insulin-like growth factor II (IGF-II) inhibits both the cellular uptake of $\beta$-galactosidase and the binding of $\beta$-galactosidase to purified IGF-II/mannose 6-phosphate receptor. J Biol Chem 264:4710-4714

21. Sklar MM, Kiess W, Thomas CL, Nissley SP 1989 Developmental expression of the tissue insulin-like growth factor II/mannose 6phosphate receptor in the rat. J Biol Chem 264:16733-16738

22. Engelmann GL, Boehm KD, Haskell JF 1989 Insulin-like growth factors and neonatal cardiomyocyte development: ventricular gen expression and membrane receptor variations in normotensive and hypertensive rats. Mol Cell Endocrinol 63:1-14

23. Vetter U, Kupferschmid C, Lang D, Pentz S 1988 Insulin-like growth factors and insulin increase the contractility of neonatal rat cardiocytes in vitro. Basic Res Cardiol 83:647 654

24. Guse AH, Berg I, Gercken G 1989 Metabolism of inositol phosphates in $\alpha_{1}$-adrenoceptor-stimulated and homogenized cardiac myocytes of adult rats. Biochem J 261:89-92

25. Legssyer A, Poggioli J, Renard D, Vassort G 1988 ATP and other adenine compounds increase mechanical activity and inositol trisphosphate production in rat heart. J Physiol 401:185-199

26. Sakuma J, Gross SS, Levi R 1988 Positive inotropic effect of histamine on guinea pig left atrium: $\mathrm{H}_{1}$-receptor-mediated stimulation of phosphoinositide turnover. J Pharmacol Exp Ther 247:466-472

27. Czech M 1989 Signal transmission by the insulin-like growth factors. Cell 59:235-238
28. Rogers SA, Hammerman MR 1988 Insulin-like growth factor II stimulates production of inositol trisphosphate in proximal tubular basolateral membranes from canine kidney. Proc Natl Acad Sci USA 85:4037-4041

29. Rogers SA, Hammerman MR 1989 Mannose 6-phosphate potentiates insulin-like growth factor II-stimulated inositol trisphosphate production in proximal tubular basolateral membranes. $J$ Biol Chem 264:4273-4276

30. Thrakker JK, DiMarchi R, MacDonald K, Caro FJ 1989 Effect of insulin and insulin-like growth factors I and II on phosphatidylinositol and phosphatidylinositol 4,5-bisphosphate breakdown in liver from humans with and without type II diabetes. J Biol Chem 264:7169-7175

31. Berg I, Guse AH, Gercken G 1989 Carbamoylcholine-induced accumulation of inositol mono-, bis-, tris- and tetrakisphosphates in isolated cardiac myocytes from adult rats. Biochim Biophys Acta 1010:100-107

32. Dean NM, Moyer JD 1987 Separation of multiple isomers of inositol phosphates formed in $\mathrm{GH}_{3}$ cells. Biochem $\mathrm{J} 242: 361-366$

33. Laemmli UK 1970 Cleavage of structural proteins during the assembly of the head of the bacteriophage T4. Nature 227:680-685

34. Kiess W, Greenstein LA, White RM, Lee L, Rechler MM, Nissley SP 1987 Type II insulin-like growth factor receptor is present in rat serum. Proc Natl Acad Sci USA 84:7720-7724

35. Kiess W, Blickenstaff GD, Sklar MM, Thomas CL, Nissley SP, Sahagian GG 1988 Biochemical evidence that the type II insulinlike growth factor receptor is identical to the cation-independent mannose 6-phosphate receptor. J Biol Chem 263:9339-9344

36. Rechler MM, Nissley SP, Podskalny JM, Moses AC, Fryklund L 1977 Identification of a receptor for somatomedin-like polypeptides in human fibroblasts. J Clin Endocrinol Metab 44:820-831

37. Dow JW, Harding NGL, Powell T 1981 Isolated cardiac myocytes. I. Preparation of adult myocytes and their homology with the intact tissue. Cardiovasc Res 215:483-514

38. Takasu N, Takasu M, Komiya I, Nagasawa Y, Asawa T, Shimizu Y, Yamada T 1989 Insulin-like growth factor I stimulates inositol phosphate accumulation, a rise in cytoplasmic free calcium, and proliferation in cultured porcine thyroid cells. J Biol Chem 264:18485-18488

39. Scholz J, Schaefer B, Schmitz W, Scholz H, Steinfath M, Lohse M, Schwabe U, Puurunen J 1988 Alpha-1 receptor-mediated positive inotropic effect and inositol trisphosphate increase in mammalian heart. J Pharmacol Exp Ther 245:327-335

40. Furlanetto RW, DiCarlo JN, Wisehart C 1987 The type II insulinlike growth factor receptor does not mediate deoxyribonucleic acid synthesis in human fibroblasts. J Clin Endocrinol Metab 64:11421149

41. Roth RA, Stover C, Hari J, Morgan DO, Smith MC, Sara V, Fried VA 1987 Interaction of the receptor for insulin-like growth factor II with mannose 6-phosphate and antibodies to the mannose 6phosphate receptor. Biochem Biophys Res Commun 149:600-606

42. Polychronakos C, Piscina R 1988 Endocytosis of receptor-bound insulin-like growth factor II is enhanced by mannose 6-phosphate in IM9 cells. Endocrinology 123:2943-2945

43. Braulke T, Causin C, Waheed A, Junghans U, Hasilik A, Maly P, Humbel RE, von Figura K 1988 Mannose 6-phosphate/insulin-like growth factor II receptor: distinct binding sites for mannose 6 phosphate and insulin-like growth factor II. Biochem Biophys Res Commun 150:1287-1293

44. Kiess W, Thomas CL, Sklar MM, Nissley SP (1990) $\beta$ Galactosidase decreases the binding affinity of the insulin-like growth-factor II/ mannose 6-phosphate receptor for insulin-like growth factor II. Eur J Biochem 190:71-77 